\section{(2) OPEN ACCESS}

\title{
Association between a 46-SNP Polygenic Risk Score and melanoma risk in Dutch patients with familial melanoma
}

\author{
Thomas P Potjer (10 , 'Tara W J van der Grinten, ${ }^{1}$ Inge M M Lakeman (D) , \\ Sander H Bollen, ${ }^{1}$ Mar Rodríguez-Girondo, ${ }^{3}$ Mark M Iles, ${ }^{4}$ Jennifer H Barrett, ${ }^{4}$ \\ Lambertus A Kiemeney, ${ }^{5,6}$ Nelleke A Gruis, ${ }^{7}$ Christi J van Asperen, ${ }^{1}$ \\ Nienke van der Stoep ${ }^{1}$
}

- Additional material is published online only. To view please visit the journal online (http://dx.doi.org/10.1136/ jmedgenet-2020-107251)

For numbered affiliations see end of article.

\section{Correspondence to}

Dr Thomas P Potjer, Department of Clinical Genetics, Leiden University Medical Center, 2333 ZA Leiden, Netherlands; T.P.Potjer@|umc.n

Received 8 June 2020 Revised 13 August 2020 Accepted 16 August 2020

Check for updates

(C) Author(s) (or their employer(s)) 2020. Re-use permitted under CC BY-NC. No commercial re-use. See rights and permissions. Published by BMJ.

\section{To cite: Potjer TP,} van der Grinten TWJ,

Lakeman IMM, et al.

$J$ Med Genet Epub ahead of print: [please include Day

Month Year]. doi:10.1136/

jmedgenet-2020-107251

\section{ABSTRACT}

Background Familial clustering of melanoma suggests a shared genetic predisposition among family members, but only $10 \%-40 \%$ of familial cases carry a pathogenic variant in a known high-risk melanoma susceptibility gene. We investigated whether a melanoma-specific Polygenic Risk Score (PRS) is associated with melanoma risk in patients with genetically unexplained familial melanoma.

Methods Dutch familial melanoma cases $(n=418)$ were genotyped for 46 SNPs previously identified as independently associated with melanoma risk. The 46-SNP PRS was calculated and standardised to 3423 healthy controls (sPRS) and the association between PRS and melanoma risk was modelled using logistic regression. Within the case series, possible differences were further explored by investigating the PRS in relation to (1) the number of primary melanomas in a patient and (2) the extent of familial clustering of melanoma.

Results The PRS was significantly associated with melanoma risk, with a per-SD OR of $2.12(95 \% \mathrm{Cl}$ 1.90 to $2.35, p<0.001)$, corresponding to a 5.70 -fold increased risk ( $95 \% \mathrm{Cl} 3.93$ to 8.28) when comparing the top 90th to the middle 40-60th PRS percentiles. The mean PRS was significantly higher in cases with multiple primary melanomas than in cases with a single melanoma (sPRS 1.17 vs $0.71, p=0.001$ ). Conversely, cases from high-density melanoma families had a lower (but non-significant) mean PRS than cases from lowdensity families (sPRS 0.60 vs $0.94, p=0.204$ ).

Conclusion Our work underlines the significance of a PRS in determining melanoma susceptibility and encourages further exploration of the diagnostic value of a PRS in genetically unexplained melanoma families.

\section{INTRODUCTION}

A major environmental risk factor for cutaneous melanoma is a high level of intermittent ultraviolet radiation exposure, especially in persons with a fair skin type. ${ }^{2}$ The incidence of melanoma has increased in European and other Western countries over the last few decades, ${ }^{34}$ so public education focusing on sun protection is increasingly important in preventing this potentially deadly disease. ${ }^{5}$ Furthermore, as up to $55 \%$ of melanoma risk may be attributable to genetic risk factors, ${ }^{6}$ people with an unfavourable genetic risk profile could potentially be enrolled in specific cancer prevention programmes. An unfavourable genetic risk profile may be related to phenotypic traits associated with melanoma risk, such as a fair skin type and a high number of (atypical) nevi, ${ }^{78}$ but other genetic risk factors are involved in less readily observable processes such as DNA repair and cell cycle control. ${ }^{9}$ When family members share genetic risk factors for melanoma and (individual or combined) risk is sufficiently strong, familial clustering of melanoma might become apparent. This effect has been clearly demonstrated for pathogenic variants in high-risk melanoma susceptibility genes with an autosomal dominant inheritance pattern, the most important of which is the cell cycle regulatory gene CDKN2A (MIM 600160). ${ }^{10}$ Nevertheless, to date only $10 \%-40 \%$ of familial clustering of melanoma can be explained by pathogenic variants in $C D K N 2 A$ or a few other rare high-risk genes (eg, CDK4, POT1, BAP1). ${ }^{1112}$

In melanoma families without identifiable variants in these high-risk genes, polygenic inheritance might explain melanoma risk, and a Polygenic Risk Score (PRS) could potentially be of considerable utility in a diagnostic setting. ${ }^{13}$ Rather than focusing on a single high-risk gene, a PRS combines the risk effect of a large number of common variants (SNPs) that have been shown to be associated with melanoma risk in genome-wide association studies (GWAS). Many of these low-risk SNPs were identified in large GWAS of patients with sporadic and familial melanoma, and several SNPs were found to be located in or near genes involved in pigmentary traits, number of nevi, DNA repair or telomere maintenance pathways. ${ }^{14-17}$ While individual SNPs have only a small effect, the combined melanoma risk in a PRS can be substantial and might therefore be useful in risk stratification. ${ }^{18}$

MC1R (MIM 155555) is a well-studied gene carrying a number of SNPs that influence melanoma risk, and several of these variants are not only statistically associated with melanoma but also have a known functional role. The MC1R gene plays an important role in skin and hair pigmentation and certain variants in this gene are strongly associated with red hair colour (RHC variants). These variants 
increase melanoma risk approximately twofold, whereas other variants less strongly associated with red hair colour (non-RHC variants) confer a smaller increase in melanoma risk. ${ }^{19}$ Extensive research in CDKN2A-mutated families has shown that both RHC and non-RHC variants modify melanoma risk in these families, ${ }^{20}{ }^{21}$ but the contribution of these variants to melanoma risk in non-CDKN2A melanoma families has been less well investigated. In a recent study, we observed a clear enrichment of $M C 1 R$ risk variants (in particular RHC variants) in Dutch melanoma families without a pathogenic variant in $C D K N 2 A,{ }^{22}$ a finding comparable to the results of earlier studies from Sweden and Denmark. ${ }^{23}{ }^{24}$ These findings collectively suggest an additional important role for $M C 1 R$ risk variants in a non-CDKN2A familial melanoma setting.

In the current study, known $M C 1 R$ risk variants and several other melanoma-associated SNPs were incorporated into a 46-SNP PRS, and the association of this PRS with melanoma risk was investigated in a series of 418 Dutch patients with familial melanoma without a pathogenic variant in high-risk melanoma susceptibility genes.

\section{METHODS}

\section{Study population}

Case series

Patients with cutaneous melanoma were recruited from Clinical Genetic Centres throughout the Netherlands. Patients were eligible for inclusion in the case series if they had at least one other relative (up to third-degree) with cutaneous melanoma and did not carry a previously identified germline mutation in the CDKN2A gene. Information on family history was obtained through detailed three-generation pedigrees drawn at the Clinical Genetic Centres. Since index patient reports of melanoma in family members have a high known level of accuracy (true positive predictive value $77 \%-87 \%),{ }^{25}$ we included in our data both confirmed and unconfirmed melanoma diagnoses reported in first-degree, second-degree and third-degree relatives. Diagnostic sequencing of the CDKN2A gene in the case series was performed at the Laboratory for Diagnostic Genome Analysis at the department of Clinical Genetics, Leiden University Medical Center. In 478 eligible cases, a multi-gene panel test including all known high and medium penetrance melanoma susceptibility genes (CDKN2A, CDK4, BAP1, POT1, ACD, TERF2IP, TERT, MITF) was performed, as described previously. ${ }^{22}$ For the purpose of this study, we excluded patients carrying a pathogenic germline variant in one of these genes $(n=18)$ or patients with a possible non-Dutch ethnicity (determined by surname, $\mathrm{n}=9$ ). To prevent oversampling of one family, only one melanoma case per family was included ( $\mathrm{n}=33$ excluded). In total, 418 cases remained for analysis (mean age 47 years), of which the majority had one or two close (first-degree or second-degree) relatives with melanoma (54\% and 34\%, respectively), and 19\% $(n=80)$ had a personal history of more than one primary melanoma (table 1). Of the first-degree and second-degree relatives with a diagnosis of melanoma (total $n=565$ relatives), 54\% were confirmed through medical records and/or pathology reports.

\section{Control series}

Healthy controls were derived from a Dutch population-based study called the Nijmegen Biomedical Study $(n=4745) .{ }^{26}$ This series was originally established to obtain a universal reference population for different types of studies, including studies of genetic variation. We first assessed whether these individuals had complete SNP data for PRS calculation ( $n=32$ excluded).

\begin{tabular}{|c|c|c|}
\hline & Cases & Controls \\
\hline Number & 418 & 3423 \\
\hline \multicolumn{3}{|l|}{ Sex } \\
\hline Male:female & $140: 278$ & $1584: 1839$ \\
\hline \multicolumn{3}{|l|}{ Age } \\
\hline Mean (range) & $47(15-87)$ & $57(30-98)$ \\
\hline \multicolumn{3}{|c|}{ No. of primary melanomas in case } \\
\hline One (\%) & $338(81)$ & - \\
\hline Two (\%) & $61(15)$ & - \\
\hline Three or more (\%) & $19(4)$ & - \\
\hline \multicolumn{3}{|c|}{$\begin{array}{l}\text { No. of first-degree or second-degree relatives } \\
\text { with melanoma }\end{array}$} \\
\hline None $(\%)^{*}$ & $16(4)$ & - \\
\hline One (\%) & $226(54)$ & - \\
\hline Two (\%) & $144(34)$ & - \\
\hline Three or more (\%) & $32(8)$ & - \\
\hline
\end{tabular}

*These cases had one or more third-degree relative(s) with melanoma.

Since this series is linked to the Netherlands Cancer Registry, we were able to exclude individuals with any type of cancer registered $(\mathrm{n}=846)$. After also excluding individuals under age 30 $(n=444)$, a total of 3423 healthy controls (mean age 57 years) with available SNP data remained for analysis (table 1).

\section{SNP selection and genotyping}

A total of 46 melanoma-associated SNPs derived from several large GWAS by the international GenoMEL consortium (https:// genomel.org/) were selected for this study (online supplemental table S1). Selection was primarily based on the significance of association with melanoma, and the fact that these SNPs were repeatedly reported and validated in independent GWAS analyses. ${ }^{14-17}$ The SNPs were identified by fine-mapping of the loci identified in Law et $a l^{17}$ and using the same methodology as in Barrett et al. ${ }^{16}$ The samples used for fine-mapping were a subset of those from Law et $a l^{17}$ totalling 12419 cases and 14242 controls (cases and controls from each centre, respectively: GenoMEL Phase 1: 1324, 3569, GenoMEL Phase 2: 1420, 4046, MDACC: 1918, 1004, AMFS: 548, 430, Q-MEGA_610k: 915, 1640, Q-MEGA_omni: 690, 553, CIDRUK: 2630, 73, MELARISK: 511, 815, WAMHS: 1252, 893, Essen-Heidelberg: 1211, 1219).

To analyse the case series, we used a custom-designed targeted sequencing panel incorporating target-specific probes that selected a minimal region of $25 \mathrm{bp}$ around the SNP. A customdesigned SNP target-specific Agilent SureSelect XT Clearseq enrichment kit was used for SNP genotyping, with sequencing based on the $200 \mathrm{ng}$ XT protocol. Capture, enrichment and sequencing were all performed at the GenomeScan sequencing facility in Leiden, and sequencing was performed on the Illumina HiSeq4000 platform to yield $150 \mathrm{bp}$, paired-end reads. Subsequent data analysis was performed using an in-house pipeline to generate the genotype data for all SNPs per sample (a description of quality control procedures used while processing the genotype data can be found in the online supplemental material).

Control SNP data were generated using the Illumina HumanOmniExpress-12 and HumanOmniExpress-24 BeadChip, and SNPs were imputed using the 1000 Genomes phase 1 v3 together with Genome of The Netherlands release 5 data as references. A detailed description of SNP genotyping, methods for imputation and quality control procedures in the control 
series can be found in the online supplemental material (and has also been published elsewhere). ${ }^{26}$

\section{Polygenic Risk Score}

The PRS was calculated for all included individuals using the formula:

PRS $=\beta_{1} x_{1}+\beta_{2} x_{2}+\beta_{3} x_{3}+\ldots \ldots+\beta_{46} x_{46}$

where $\beta$ is the per-allele log OR for melanoma associated with the risk allele of the SNP, and $x$ the number of risk alleles per SNP $(0,1$, or 2$)$. The ORs were the most recent estimates from the melanoma GWAS analyses of the GenoMEL consortium (online supplemental table S1). ${ }^{17}$ To facilitate comparison between the case and control series, the PRS was standardised (sPRS) to the mean and SD in the control series. The mean sPRS in population controls was therefore 0 with an SD of 1.

\section{Statistical analysis}

Association between PRS and melanoma risk was modelled using logistic regression, and reported ORs represented the OR per unit SD of the sPRS in the control series. The regression model was adjusted for age and sex. We also estimated the association by percentile groups of the sPRS in the control series, with the middle 40-60th percentile used as reference. The discriminative ability of the PRS model was assessed with Area Under the receiver-operating Curve (AUC) analysis. To further investigate possible differences in the PRS between cases with either one or multiple primary melanomas, we compared the mean sPRS between these two subgroups using the t-test for independent samples. We also investigated whether the extent of familial clustering for melanoma was correlated with the PRS using the Pearson correlation test. Familial clustering was quantified with a weighted proportion of relatives with a medical history of melanoma. First-degree relatives contribute with weight 0.5 and second-degree relatives contribute with weight 0.25 . Relatives with multiple primary melanomas contributed with the number of primary melanomas they were diagnosed with. This resulted in the following 'Familial Clustering Score' (FCS):

$$
F C S=\frac{F_{m e l} * 0.5+S_{m e l} * 0.25+\left(M_{F}-F_{m e l}\right) * 0.5+\left(M_{S}-S_{m e l}\right) * 0.25}{F_{t o t} * 0.5+S_{t o t} * 0.25+\left(M_{F}-F_{m e l}\right) * 0.5+\left(M_{S}-S_{m e l}\right) * 0.25}
$$

where $\mathrm{F}_{\text {tot }}$ and $\mathrm{S}_{\text {tot }}$ are the total number of first-degree and second-degree relatives, $\mathrm{F}_{\text {mel }}$ and $\mathrm{S}_{\text {mel }}$ are the number of firstdegree and second-degree relatives with melanoma, and $M_{F}$ and $\mathrm{M}_{\mathrm{S}}$ are the total number of primary melanomas in first-degree and second-degree relatives, respectively. An FCS could be calculated for a total of 369 cases (49 cases were excluded due to incomplete pedigree information). Using the t-test for independent samples, we compared the mean sPRS between cases with the lowest 10\% FCS and cases with the highest 10\% FCS. These analyses were repeated using an alternative FCS that was based solely on the number of relatives with melanoma (thus ignoring the number of primary melanomas in a relative). We reported 95\% CIs and considered p-values statistically significant at the $5 \%$ level $(\alpha=0.05)$.

\section{RESULTS}

\section{Association between PRS and melanoma risk}

On average, familial melanoma cases had a higher PRS than healthy controls, with a mean sPRS in the case series of 0.80 $(\mathrm{SD}=1.14,95 \% \mathrm{CI} 0.69$ to 0.91$)$ versus the control figure set at 0 (table 2, figure 1A). Using logistic regression, we also found a significant association between PRS and melanoma risk, with a per-SD OR of 2.12 (95\% CI 1.90 to $2.35, \mathrm{p}<0.001)$. The 46-SNP PRS model had an AUC of 0.77 (95\% CI 0.75 to 0.79 ).
Table 2 Descriptive analysis of the 46-SNP PRS

\begin{tabular}{|c|c|c|c|c|}
\hline & \multirow[b]{2}{*}{$\mathrm{n}$} & \multicolumn{3}{|l|}{ sPRS } \\
\hline & & Mean & SD & $95 \% \mathrm{Cl}$ \\
\hline Familial melanoma cases & 418 & 0.80 & 1.14 & 0.69 to 0.91 \\
\hline \multicolumn{5}{|l|}{$\begin{array}{l}\text { No. of primary melanomas } \\
\text { in case }\end{array}$} \\
\hline One & 338 & 0.71 & 1.11 & 0.59 to 0.83 \\
\hline Two or more & 80 & 1.17 & 1.23 & 0.90 to 1.44 \\
\hline \multicolumn{5}{|l|}{ Family Clustering Score } \\
\hline Lowest $10 \%$ & 39 & 0.94 & 1.26 & 0.55 to 1.33 \\
\hline Middle $10 \%-90 \%$ & 288 & 0.85 & 1.16 & 0.72 to 0.98 \\
\hline Highest $10 \%$ & 42 & 0.60 & 1.17 & 0.25 to 0.95 \\
\hline Population controls & 3423 & 0 & 1 & -0.03 to 0.03 \\
\hline
\end{tabular}

PRS, Polygenic Risk Score; sPRS, standardised PRS.

After assigning the cases to percentile groups of the PRS distribution determined using the control series, a significant association was found between a PRS above the 60th percentile and melanoma risk (figure 2). Compared with individuals with a PRS in the 40-60th percentile, individuals with a PRS in the 60-80th percentile had an OR of 2.06 (95\% CI 1.41 to 3.00) for developing melanoma, individuals in the 80-90th percentile had an OR of 3.27 (95\% CI 2.19 to 4.88) and individuals above the 90th percentile had an OR of 5.70 (95\% CI 3.93 to 8.28).

To further explore possible differences in the PRS for cases with multiple primary melanomas $(n=80)$ and cases with a single melanoma $(n=338)$, we compared the mean sPRS for
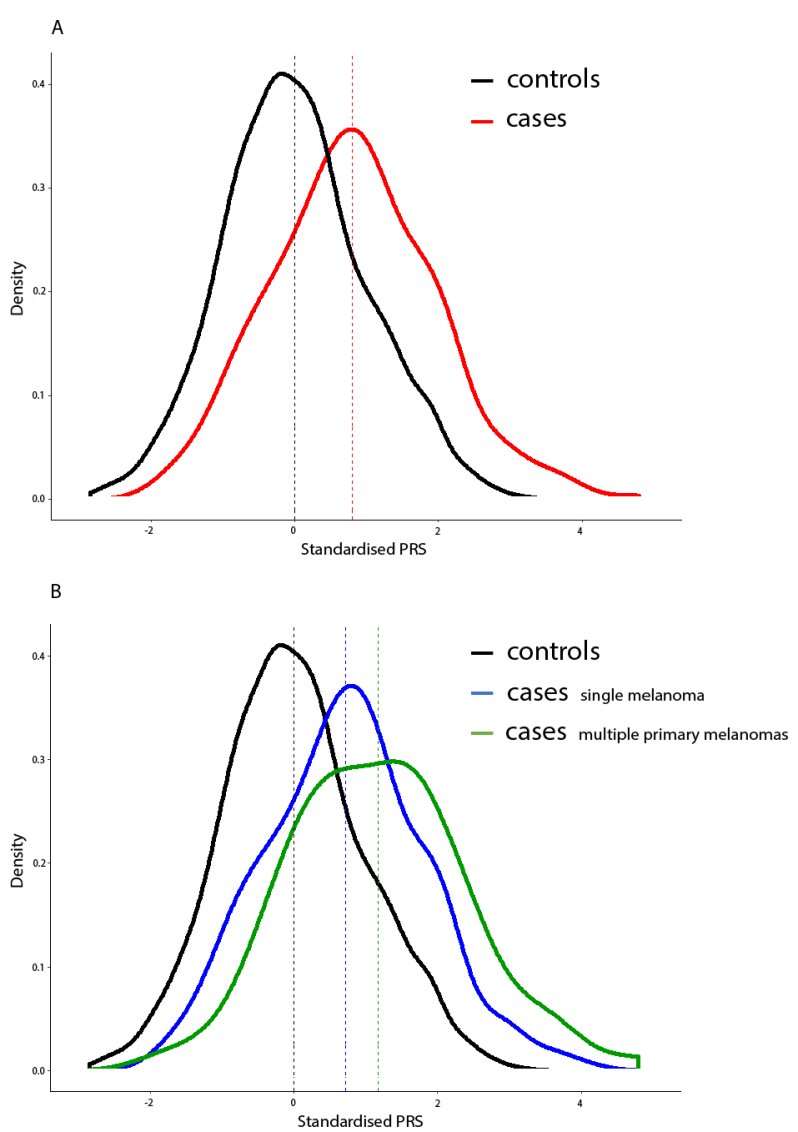

Figure 1 Distribution of the standardised PRS in (A) all 418 cases combined (red), (B) cases divided into those with a single melanoma (blue) and those with multiple primary melanomas (green). Dotted lines correspond to the means (see table 1). PRS, Polygenic Risk Score. 


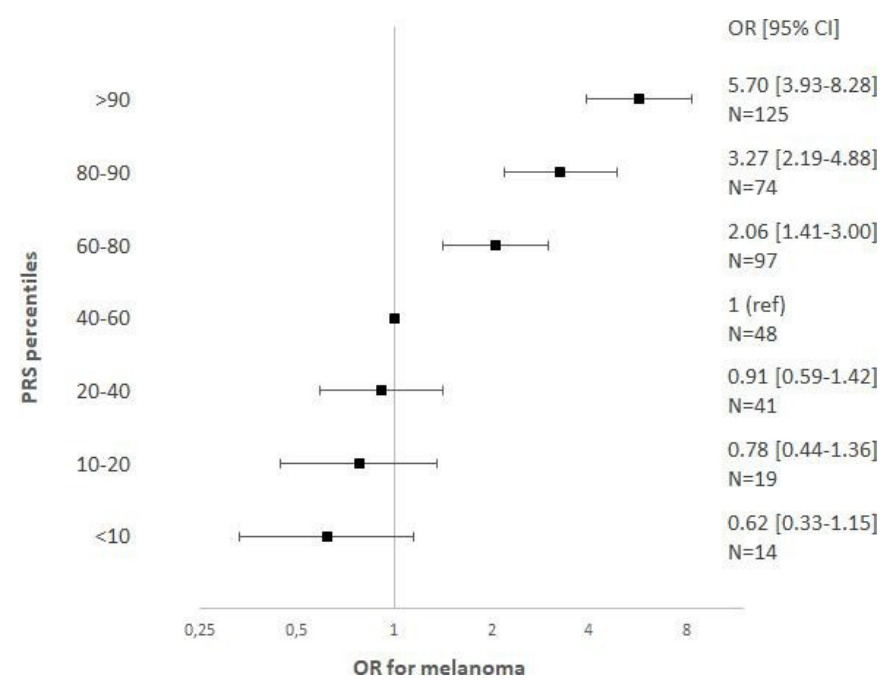

Figure 2 Estimated effect sizes by percentile of the standardised PRS. PRS, Polygenic Risk Score; ref, reference.

these two groups. The distributions of the sPRS for the two groups and the control series are displayed in figure 1B. The mean sPRS in cases with multiple primary melanomas $(1.17$, $95 \%$ CI 0.90 to 1.44 ) was significantly higher than the mean sPRS in cases with a single melanoma $(0.71,95 \% \mathrm{CI} 0.59$ to $0.83)(p=0.001)$. The per-SD OR for an association between the PRS and melanoma risk increased significantly, from 1.98 $(95 \%$ CI 1.77 to $2.22, \mathrm{p}<0.001)$ for single melanoma to $2.86(95 \%$ CI 2.30 to $3.55, \mathrm{p}<0.001)$ for multiple primary melanomas $(p=0.003)$. The proportion of cases with two or more first-degree or second-degree relatives with melanoma was similar among cases with a single melanoma (42\%) and cases with multiple primary melanomas $(39 \%)(\mathrm{p}=0.625)$, indicating that it is unlikely that these results were biassed by family history.

Additionally, we calculated an FCS for each case as described in the Methods section, but found no significant correlation between FCS and PRS $\left(\mathrm{R}^{2}=0.003\right.$, Pearson correlation test: $p=0.283$ ). A comparison between cases with the highest $10 \%$ FCS (high-density melanoma families, $n=42$ ) and cases with the lowest 10\% FCS (low-density melanoma families, $\mathrm{n}=39$ ) revealed that cases from low-density melanoma families had a higher mean sPRS $(0.94,95 \%$ CI 0.55 to 1.33$)$ than cases from high-density melanoma families $(0.60,95 \% \mathrm{CI} 0.25$ to 0.95$)$ (table 2), although this difference did not reach statistical significance $(p=0.204)$. Of note, the low-density melanoma families were not enriched for cases with multiple primary melanomas $(8 / 39$ cases $(21 \%)$ had multiple primary melanomas, vs $80 / 418$ cases $(19 \%)$ in the total study population; $\mathrm{p}=0.762$ ), and vice versa, the high-density melanoma families were not enriched for cases with a single melanoma $(36 / 42$ cases $(86 \%)$ had a single melanomas, vs $338 / 418$ cases $(81 \%)$ in the total study population; $\mathrm{p}=0.427$ ), so a potential bias related to the number of primary melanomas in these cases is unlikely. The distributions of the sPRSs for the three groups and the control series are displayed in online supplemental figure S1. In addition, the alternative FCS (which ignored the number of primary melanomas in a relative) did not show a significant correlation with the PRS as well $\left(\mathrm{R}^{2}=0.008\right.$, Pearson correlation test: $\mathrm{p}=0.096)$. However, when compared with the analyses with the original FCS, an even greater difference in mean sPRS was observed between cases from low-density melanoma families $(0.97,95 \% \mathrm{CI} 0.57$ to 1.37$)$ and cases from high-density melanoma families $(0.49,95 \%$ CI 0.13 to 0.85$)$ $(p=0.088)$, a difference principally attributable to a decrease in mean sPRS in high-density melanoma families (from 0.60 in the original FCS to 0.49 in the alternative FCS)

\section{Analysis of the PRS in an additional 15 cases with the MITF p.E318K variant}

In our previous multi-gene panel sequencing study, from which we derived the case series for the current study, we identified 15 familial melanoma cases with the moderate penetrance variant c.952G >A, p.E318K (RefSeq NM_000248.3) in the MITF gene (MIM 156845). ${ }^{22}$ Although these 15 cases were excluded from the case series of the current study, PRS data were also available for these cases. To explore whether the PRS might be a potential modifier of melanoma risk in these families, we performed a descriptive analysis in this small group and found that 11 out of $15(73 \%)$ cases with the MITF p.E318K variant had a PRS above the 60th percentile of the PRS distribution, including seven (47\%) with a PRS above the 90th percentile.

\section{DISCUSSION}

In this study, we found that a 46-SNP PRS is significantly associated with melanoma risk in a large series of familial cases ascertained through Clinical Genetic Centres in the Netherlands. Melanoma cases had, on average, a higher PRS than healthy controls, and individuals in the top 90th percentile of the PRS were 5.7 times more likely to have melanoma compared with individuals in the middle 40-60th percentile. Since our familial cases were all previously screened for pathogenic variants in currently known high-risk melanoma susceptibility genes, these results contribute to our understanding of (poly)gen(et)ic risk in genetically unexplained melanoma families.

Although no previous study has specifically investigated a melanoma PRS in familial cases, several recent populationbased melanoma PRS studies have reported similar findings. A US study reported a 1.9-fold increased melanoma risk for individuals in the highest tertile of a 21-SNP PRS compared with individuals in the lowest tertile. ${ }^{27}$ In another study that investigated a 45-SNP PRS that was almost identical to the PRS in our study, the per-SD OR was 1.75 in an Australian cohort and 1.63 in a UK cohort. ${ }^{28} \mathrm{~A}$ third study that validated a 204-SNP PRS in a cohort of Southern European individuals reported a per-quintile OR for melanoma of 1.35 , which corresponded to a 3.33 -fold increased risk for individuals in the highest quintile ( $>80$ th percentile) compared with individuals in the lowest quintile ( $<20$ th percentile). ${ }^{29}$ Although it is difficult to directly compare our results to the associations found in these studies, our reported per-SD OR of 2.12 seems relatively high, which might suggest a more important role for the PRS in a familial setting.

We also found that cases with multiple primary melanomas had a significantly higher mean PRS than cases with a single melanoma. The per-SD OR increased to 2.86 for multiple primary melanomas, providing further support for an association between the PRS and melanoma risk. This finding indicates that individuals with a high PRS not only have a higher chance of developing melanoma but also a higher chance of developing subsequent melanomas. Although the development of subsequent tumours has not been previously investigated for melanoma, breast cancer PRS studies have reported similar findings, with bilateral breast cancer cases showing a higher PRS compared with unilateral breast cancer cases. ${ }^{30-32}$ Further exploration of 
the differences in the PRS between cases with higher or lower numbers of multiple primary melanomas would be interesting, as the association might strengthen as the number of detected melanomas increases. As only $4 \%$ of cases in our series had three or more primary melanomas, these additional analyses could not be performed within the context of the present study. However, as multiple primary melanomas are not unusual in patients with sporadic melanoma, these analyses should be possible in larger population-based studies. ${ }^{33}$

To explore possible differences in PRS between cases from high-density versus low-density melanoma families, we calculated an FCS for each case based on the number of close family members with melanoma relative to the family size. Although the FCS and PRS were not significantly correlated in our cases, we did observe an inverse (non-significant) relationship between PRS and FCS, that is, cases with a high FCS had a relatively low PRS and vice versa. The inverted relationship between PRS and FCS became even more apparent in the analyses with the alternative FCS, in which we ignored the number of primary melanomas in a family member. These observations might suggest that the PRS plays a less important role in high-density melanoma families. If confirmed, one possible explanation might be a still unidentified pathogenic variant in a (known or unknown) highrisk melanoma susceptibility gene or other genomic regulatory region that explains the strong familial clustering of melanoma, which often appears to follow an autosomal dominant inheritance pattern. This inheritance pattern is itself best reflected in the alternative FCS that was solely based on the number of relatives with melanoma, and the inverted relationship between PRS and FCS was indeed most obvious in analyses with the alternative FCS. Further studies in independent familial melanoma cohorts should now be performed to determine whether these differences can be replicated and are indeed significant.

In addition, we conducted an analysis of the PRS in carriers of the MITF p.E318K risk variant and found that the distribution of the PRS in these carriers was strongly skewed towards the 90th percentile ( $47 \%$ above the 90 th percentile). This observation is consistent with the hypothesis that carriers of a mediumpenetrance risk variant like MITF p.E318K require additional (genetic) risk factors in order to develop melanoma, ${ }^{34} 35$ and suggests that a high PRS may indeed represent an additional risk factor. Further assessment of the PRS in a larger group of MITF families, including carriers without melanoma, will likely provide more insight into the precise relationship between MITF, PRS and melanoma risk.

A major strength of our study is the composition of the case series, as only melanoma cases with a positive family history for melanoma were included. Familial melanoma is likely to have a stronger genetic aetiology compared with sporadic melanoma, where environmental factors may be more important. An additional strength is the ascertainment of cases through Clinical Genetic Centres, facilitating the inclusion of extensive threegeneration pedigrees for most cases (only 12\% had incomplete pedigree information). Furthermore, the study population (both cases and controls) consisted entirely of Dutch individuals and therefore genetic variability due to ethnic differences was probably very low. Finally, our PRS model was based on a refined selection of 46 highly significant SNPs that have been repeatedly identified in large independent GWA studies.

Two limitations should be noted. First, we did not include traditional risk factors (eg, hair and skin colour, nevus density, sun exposure) in our analysis of predictive performance. Nonetheless, our reported AUC of 0.77 is comparable to studies that included these traditional risk factors. In a study by Cust et $a l$, a moderate improvement in risk prediction of 2.3\% (AUC 0.74; Australian cohort) and 2.8\% (AUC 0.68; UK cohort) was observed after the PRS was included in a risk prediction model based on traditional risk factors, ${ }^{28}$ and $\mathrm{Gu}$ et al reported an improvement of 0.4\% (AUC 0.89; Spanish cohort), 1.4\% (AUC 0.69; Italian cohort) and 1.9\% (AUC 0.72; Greek cohort). ${ }^{29}$ Combining a PRS with these traditional risk factors seems to improve the predictive capability of the model, although one should be aware of recall bias when including traditional risk factors like sun exposure and history of sunburns. A second possible limitation is that we developed an FCS that has not been scientifically evaluated as a tool to assess melanoma risk based on family history. However, to our knowledge no other similar tool is currently available for familial melanoma. Therefore, until a more statistically robust tool becomes available, the results from our FCS analysis should be interpreted with caution.

In conclusion, our findings underline the significance of the PRS in determining melanoma susceptibility and represent an important preliminary exploration of the value of a PRS in genetically unexplained melanoma families. The PRS had a fairly good ability to predict melanoma risk in our series of familial cases, but independent validation will be needed to confirm this finding. To further understand the role of the PRS in a familial setting, analysis of the PRS in multiple (un)affected family members of our cases, and including a non-familial (sporadic) melanoma cohort for comparison, will be necessary. A better understanding of genetic risk in these families may eventually lead to better and more personalised melanoma surveillance strategies.

\section{Author affiliations}

'Department of Clinical Genetics, Leiden University Medical Center, Leiden, The Netherlands

${ }^{2}$ Department of Human Genetics, Leiden University Medical Center, Leiden, The Netherlands

${ }^{3}$ Department of Biomedical Data Sciences, Leiden University Medical Center, Leiden, The Netherlands

${ }^{4}$ Section of Epidemiology and Biostatistics, Leeds Institute of Cancer and Pathology, Leeds, UK

${ }^{5}$ Department of Health Sciences, Radboud University Medical Center, Nijmegen, The Netherlands

${ }^{6}$ Department of Urology, Radboud University Medical Center, Nijmegen, The Netherlands

${ }^{7}$ Department of Dermatology, Leiden University Medical Center, Leiden, The Netherlands

Acknowledgements We thank the following representatives from the Dutch Working Group for Clinical Oncogenetics for their assistance in acquiring the family pedigrees of study participants: Anja Wagner, Lizet van der Kolk, Margreet Ausems, Theo Van Os, Kim van Kaam, Liesbeth Spruijt, Charlotte Dommering, Peter van den Akker. We thank Tessel Galesloot from the Nijmegen Biomedical Study (NBS) for her assistance in acquiring the NBS data, and we thank Comprehensive Cancer Centre of the Netherlands for the collection of data for the Netherlands Cancer Registry which was part of the NBS data. From GenoMEL, we thank Peter Kanetsky and Tim Bishop for their valuable input during study design and Matthew Law, Alisa Goldstein and Anne Cust for their critical review of this study. We also thank Marjanka Schmidt for sharing her expertise in methodology.

Contributors Design and conception of study: TPP, NS, NAG. Data collection and assembly: TPP, TWJG, SHB, MMI. Data analysis and interpretation: TPP, TWJG, IMML, MR-G, NS. Writing of manuscript: TPP, TWJG, NS. Critical review and revision of manuscript: all authors. Submission of manuscript: TPP.

Funding This work was supported by the Dutch Cancer Society (\#UL 2015-7511 to TPP and NS).

Competing interests None declared.

Patient consent for publication Not required.

Ethics approval The study was approved by the LUMC Ethics Committee (\#P15.341) and informed consent was obtained from all included individuals.

Provenance and peer review Not commissioned; externally peer reviewed. 
Data availability statement Study data are available upon reasonable request from TPP (T.P.Potjer@lumc.nl).

Open access This is an open access article distributed in accordance with the Creative Commons Attribution Non Commercial (CC BY-NC 4.0) license, which permits others to distribute, remix, adapt, build upon this work non-commercially, and license their derivative works on different terms, provided the original work is properly cited, appropriate credit is given, any changes made indicated, and the use is non-commercial. See: http://creativecommons.org/licenses/by-nc/4.0/.

\section{ORCID iDs}

Thomas P Potjer http://orcid.org/0000-0002-3831-6022

Inge M M Lakeman http://orcid.org/0000-0002-2990-7154

\section{REFERENCES}

1 Gandini S, Sera F, Cattaruzza MS, Pasquini P, Picconi O, Boyle P, Melchi CF. MetaAnalysis of risk factors for cutaneous melanoma: II. sun exposure. Eur J Cancer 2005;41:45-60.

2 Bataille V, de Vries E. Melanoma--Part 1: epidemiology, risk factors, and prevention. BMJ 2008;337:a2249.

3 Erdmann F, Lortet-Tieulent J, Schüz J, Zeeb H, Greinert R, Breitbart EW, Bray F. International trends in the incidence of malignant melanoma 1953-2008--are recent generations at higher or lower risk? Int J Cancer 2013;132:385-400.

4 Sacchetto L, Zanetti R, Comber H, Bouchardy C, Brewster DH, Broganelli P, Chirlaque MD, Coza D, Galceran J, Gavin A, Hackl M, Katalinic A, Larønningen S, Louwman MWJ, Morgan E, Robsahm TE, Sanchez MJ, Tryggvadóttir L, Tumino R, Van Eycken E, Vernon S, Zadnik V, Rosso S. Trends in incidence of thick, thin and in situ melanoma in Europe. Eur J Cancer 2018;92:108-18.

5 Glanz K, Volpicelli K, Jepson C, Ming ME, Schuchter LM, Armstrong K. Effects of tailored risk communications for skin cancer prevention and detection: the PennSCAPE randomized trial. Cancer Epidemiol Biomarkers Prev 2015;24:415-21.

6 Shekar SN, Duffy DL, Youl P, Baxter AJ, Kvaskoff M, Whiteman DC, Green AC, Hughes MC, Hayward NK, Coates M, Martin NG. A population-based study of Australian twins with melanoma suggests a strong genetic contribution to liability. J Invest Dermatol 2009;129:2211-9.

7 Gandini S, Sera F, Cattaruzza MS, Pasquini P, Abeni D, Boyle P, Melchi CF. MetaAnalysis of risk factors for cutaneous melanoma: I. common and atypical naevi. Eur J Cancer 2005:41:28-44

8 Gandini S, Sera F, Cattaruzza MS, Pasquini P, Zanetti R, Masini C, Boyle P, Melchi CF. Meta-Analysis of risk factors for cutaneous melanoma: III. family history, actinic damage and phenotypic factors. Eur J Cancer 2005;41:2040-59.

9 Law MH, Macgregor S, Hayward NK. Melanoma genetics: recent findings take us beyond well-traveled pathways. J Invest Dermatol 2012;132:1763-74.

10 Goldstein AM, Chan M, Harland M, Gillanders EM, Hayward NK, Avril M-F, Azizi E, Bianchi-Scarra G, Bishop DT, Bressac-de Paillerets B, Bruno W, Calista D, Cannon Albright LA, Demenais F, Elder DE, Ghiorzo P, Gruis NA, Hansson J, Hogg D, Holland EA, Kanetsky PA, Kefford RF, Landi MT, Lang J, Leachman SA, Mackie RM, Magnusson V, Mann GJ, Niendorf K, Newton Bishop J, Palmer JM, Puig S, Puig-Butille JA, de Snoo FA, Stark M, Tsao H, Tucker MA, Whitaker L, Yakobson E, Melanoma Genetics Consortium (GenoMEL). High-Risk melanoma susceptibility genes and pancreatic cancer, neural system tumors, and uveal melanoma across GenoMEL. Cancer Res 2006:66:9818-28.

11 Aoude LG, Wadt KAW, Pritchard AL, Hayward NK. Genetics of familial melanoma: 20 years after CDKN2A. Pigment Cell Melanoma Res 2015;28:148-60.

12 Read J, Wadt KAW, Hayward NK. Melanoma genetics. J Med Genet 2016;53:1-14.

13 Torkamani A, Wineinger NE, Topol EJ. The personal and clinical utility of polygenic risk scores. Nat Rev Genet 2018;19:581-90.

14 Bishop DT, Demenais F, Iles MM, Harland M, Taylor JC, Corda E, Randerson-Moor J, Aitken JF, Avril M-F, Azizi E, Bakker B, Bianchi-Scarrà G, Bressac-de Paillerets B, Calista D, Cannon-Albright LA, Chin-A-Woeng T, Debniak T, Galore-Haskel G, Ghiorzo P, Gut I, Hansson J, Hocevar M, Höiom V, Hopper JL, Ingvar C, Kanetsky PA, Kefford RF, Landi MT, Lang J, Lubiński J, Mackie R, Malvehy J, Mann GJ, Martin NG, Montgomery GW, van Nieuwpoort FA, Novakovic S, Olsson H, Puig S, Weiss M, van Workum W, Zelenika D, Brown KM, Goldstein AM, Gillanders EM, Boland A, Galan P, Elder DE, Gruis NA, Hayward NK, Lathrop GM, Barrett JH, Bishop JAN. Genome-Wide association study identifies three loci associated with melanoma risk. Nat Genet 2009;41:920-5.

15 Barrett JH, lles MM, Harland M, Taylor JC, Aitken JF, Andresen PA, Akslen LA, Armstrong BK, Avril M-F, Azizi E, Bakker B, Bergman W, Bianchi-Scarrà G, Bressacde Paillerets B, Calista D, Cannon-Albright LA, Corda E, Cust AE, Dębniak T, Duffy D, Dunning AM, Easton DF, Friedman E, Galan P, Ghiorzo P, Giles GG, Hansson J, Hocevar M, Höiom V, Hopper JL, Ingvar C, Janssen B, Jenkins MA, Jönsson G, Kefford RF, Landi G, Landi MT, Lang J, Lubiński J, Mackie R, Malvehy J, Martin NG, Molven A, Montgomery GW, van Nieuwpoort FA, Novakovic S, Olsson H, Pastorino L, Puig S, Puig-Butille JA, Randerson-Moor J, Snowden H, Tuominen R, Van Belle P, van der Stoep N, Whiteman DC, Zelenika D, Han J, Fang S, Lee JE, Wei Q, Lathrop GM, Gillanders EM, Brown KM, Goldstein AM, Kanetsky PA, Mann GJ, Macgregor S, Elder DE, Amos Cl, Hayward NK, Gruis NA, Demenais F, Bishop JAN, Bishop DT, GenoMEL
Consortium. Genome-Wide association study identifies three new melanoma susceptibility loci. Nat Genet 2011;43:1108-13.

16 Barrett JH, Taylor JC, Bright C, Harland M, Dunning AM, Akslen LA, Andresen PA, Avril M-F, Azizi E, Bianchi Scarrà G, Brossard M, Brown KM, Dębniak T, Elder DE, Friedman E, Ghiorzo P, Gillanders EM, Gruis NA, Hansson J, Helsing P, Hočevar M, Höiom V, Ingvar C, Landi MT, Lang J, Lathrop GM, Lubiński J, Mackie RM, Molven A, Novaković S, Olsson H, Puig S, Puig-Butille JA, van der Stoep N, van Doorn R, van Workum W, Goldstein AM, Kanetsky PA, Pharoah PDP, Demenais F, Hayward NK, Newton Bishop JA, Bishop DT, Iles MM, GenoMEL Consortium. Fine mapping of genetic susceptibility loci for melanoma reveals a mixture of single variant and multiple variant regions. Int J Cancer 2015;136:1351-60.

17 Law MH, Bishop DT, Lee JE, Brossard M, Martin NG, Moses EK, Song F, Barrett JH, Kumar R, Easton DF, Pharoah PDP, Swerdlow AJ, Kypreou KP, Taylor JC, Harland M, Randerson-Moor J, Akslen LA, Andresen PA, Avril M-F, Azizi E, Scarrà GB, Brown KM, Dębniak T, Duffy DL, Elder DE, Fang S, Friedman E, Galan P, Ghiorzo P, Gillanders EM, Goldstein AM, Gruis NA, Hansson J, Helsing P, Hočevar M, Höiom V, Ingvar C, Kanetsky PA, Landi MT, Lang J, Lathrop GM, Lubiński J, Mackie RM, Mann GJ, Molven A, Montgomery GW, Novaković S, Olsson H, Puig S, Puig-Butille JA, Qureshi AA, Radford-Smith GL, van der Stoep N, van Doorn R, Whiteman DC, Craig JE, Schadendorf D, Simms LA, Burdon KP, Nyholt DR, Pooley KA, Orr N, Stratigos AJ, Cust AE, Ward SV, Hayward NK, Han J, Schulze H-J, Dunning AM, Bishop JAN, Demenais F, Amos Cl, MacGregor S, lles MM, GenoMEL Consortium, EssenHeidelberg Investigators, SDH Study Group, Q-MEGA and QTWIN Investigators, AMFS Investigators, ATHENS Melanoma Study Group. Genome-Wide meta-analysis identifies five new susceptibility loci for cutaneous malignant melanoma. Nat Genet 2015;47:987-95

18 Roberts MR, Asgari MM, Toland AE. Genome-Wide association studies and polygenic risk scores for skin cancer: clinically useful yet? Br J Dermatol 2019;181:1146-55.

19 Raimondi S, Sera F, Gandini S, lodice S, Caini S, Maisonneuve P, Fargnoli MC. Mc1R variants, melanoma and red hair color phenotype: a meta-analysis. Int $J$ Cancer 2008; 122:2753-60.

20 Demenais F, Mohamdi H, Chaudru V, Goldstein AM, Newton Bishop JA, Bishop DT, Kanetsky PA, Hayward NK, Gillanders E, Elder DE, Avril MF, Azizi E, van Belle P, Bergman W, Bianchi-Scarrà G, Bressac-de Paillerets B, Calista D, Carrera C, Hansson J, Harland M, Hogg D, Höiom V, Holland EA, Ingvar C, Landi MT, Lang JM, Mackie RM, Mann GJ, Ming ME, Njauw CJ, Olsson H, Palmer J, Pastorino L, Puig S, RandersonMoor J, Stark M, Tsao H, Tucker MA, van der Velden P, Yang XR, Gruis N, Melanoma Genetics Consortium. Association of MC1R variants and host phenotypes with melanoma risk in CDKN2A mutation carriers: a GenoMEL study. J Nat/ Cancer Inst 2010;102:1568-83.

21 Fargnoli MC, Gandini S, Peris K, Maisonneuve P, Raimondi S. Mc1R variants increase melanoma risk in families with CDKN2A mutations: a meta-analysis. Eur $J$ Cancer 2010;46:1413-20.

22 Potjer TP, Bollen S, Grimbergen AJEM, van Doorn R, Gruis NA, van Asperen CJ, Hes FJ, van der Stoep N, Dutch Working Group for Clinical Oncogenetics. Multigene panel sequencing of established and candidate melanoma susceptibility genes in a large cohort of Dutch non-CDKN2A/CDK4 melanoma families. Int J Cancer 2019;144:2453-64.

23 Höiom V, Tuominen R, Käller M, Lindén D, Ahmadian A, Månsson-Brahme E, Egyhazi S, Sjöberg K, Lundeberg J, Hansson J. Mc1R variation and melanoma risk in the Swedish population in relation to clinical and pathological parameters. Pigment Cell Melanoma Res 2009:22:196-204.

24 Wadt KAW, Aoude LG, Krogh L, Sunde L, Bojesen A, Grønskov K, Wartacz N, Ek J, Tolstrup-Andersen M, Klarskov-Andersen M, Borg Åke, Heegaard S, Kiilgaard JF, Hansen TVO, Klein K, Jönsson G, Drzewiecki KT, Dunø M, Hayward NK, Gerdes A-M. Molecular characterization of melanoma cases in Denmark suspected of genetic predisposition. PLoS One 2015;10:e0122662.

25 Wadt KAW, Drzewiecki KT, Gerdes A-M. High accuracy of family history of melanoma in Danish melanoma cases. Fam Cancer 2015;14:609-13.

26 Galesloot TE, Vermeulen SH, Swinkels DW, de Vegt F, Franke B, den Heijer M, de Graaf J, Verbeek ALM, Kiemeney LALM. Cohort profile: the Nijmegen biomedical study (Nbs). Int J Epidemiol 2017;46:1099-100.

27 Cho HG, Ransohoff KJ, Yang L, Hedlin H, Assimes T, Han J, Stefanick M, Tang JY, Sarin KY. Melanoma risk prediction using a multilocus genetic risk score in the women's health Initiative cohort. J Am Acad Dermatol 2018;79:36-41.

28 Cust AE, Drummond M, Goldstein AM, Barrett JH, MacGregor S, Law MH, Iles MM, Bui M, Hopper JL, Brossard M, Demenais F, Taylor JC, Hoggart C, Brown KM, Landi MT, Newton-Bishop JA, Mann GJ, Bishop DT, Australian Melanoma Family Study Investigators, Leeds Case-Control Study Investigators. Assessing the incremental contribution of common genomic variants to melanoma risk prediction in two population-based studies. J Invest Dermatol 2018;138:2617-24.

29 Gu F, Chen T-H, Pfeiffer RM, Fargnoli MC, Calista D, Ghiorzo P, Peris K, Puig S, Menin C, De Nicolo A, Rodolfo M, Pellegrini C, Pastorino L, Evangelou E, Zhang T, Hua X, DellaValle CT, Timothy Bishop D, MacGregor S, lles MI, Law MH, Cust A, Brown KM, Stratigos AJ, Nagore E, Chanock S, Shi J, Consortium MM-A, Consortium M, Landi MT. Combining common genetic variants and non-genetic risk factors to predict risk of cutaneous melanoma. Hum Mol Genet 2018;27:4145-56. 
30 Sawyer S, Mitchell G, McKinley J, Chenevix-Trench G, Beesley J, Chen XQ, Bowtell D, Trainer AH, Harris M, Lindeman GJ, James PA. A role for common genomic variants in the assessment of familial breast cancer. J Clin Oncol 2012;30:4330-6.

31 Robson ME, Reiner AS, Brooks JD, Concannon PJ, John EM, Mellemkjaer L, Bernstein L, Malone KE, Knight JA, Lynch CF, Woods M, Liang X, Haile RW, Duggan DJ, Shore RE, Smith SA, Thomas DC, Stram DO, Bernstein JL, WECARE Study Collaborative Group. Association of common genetic variants with contralateral breast cancer risk in the WECARE study. J Nat/ Cancer Inst 2017:109:1-3.

32 Lakeman IMM, Hilbers FS, Rodríguez-Girondo M, Lee A, Vreeswijk MPG, Hollestelle A, Seynaeve C, Meijers-Heijboer H, Oosterwijk JC, Hoogerbrugge N, Olah E, Vasen
HFA, van Asperen CJ, Devilee P. Addition of a 161-SNP polygenic risk score to family history-based risk prediction: impact on clinical management in non-BRCA1/2 breast cancer families. J Med Genet 2019;56:581-9.

33 Moore MM, Geller AC, Warton EM, Schwalbe J, Asgari MM. Multiple primary melanomas among 16,570 patients with melanoma diagnosed at Kaiser Permanente Northern California, 1996 to 2011. J Am Acad Dermatol 2015;73:630-6.

34 Paillerets BB-de, Lesueur F, Bertolotto C. A germline oncogenic MITF mutation and tumor susceptibility. Eur J Cell Biol 2014;93:71-5.

35 Bressac-de Paillerets B, Vabres P, Thomas L. Genetic testing for Melanoma-Where are we with Moderate-Penetrance genes? JAMA Dermatol 2016;152:375-6. 